\title{
Effect of exogenous oestradiol-17 $\beta$ on gonadotrophin secretion in post-partum beef cows
}

\author{
A. R. Peters* \\ AFRC Research on Hormones and Farm Animal Reproduction, University of Nottingham, \\ School of Agriculture, Sutton Bonington, Loughborough, Leicestershire LE12 5RD, U.K.
}

\begin{abstract}
Summary. Twelve cows between Days 10 and 17 post partum received one or two silicone rubber implants, each containing $45 \mathrm{mg}$ oestradiol-17ß. Plasma oestradiol concentrations increased from $4.25 \pm 0.51 \mathrm{pg} / \mathrm{ml}$ before implant insertion to $16.57 \pm$ $3.66 \mathrm{pg} / \mathrm{ml}$ (one implant) and $37 \cdot 10 \pm 9 \cdot 1 \mathrm{pg} / \mathrm{ml}$ (two implants) during the 5 days of implant treatment. Preovulatory-type LH and FSH surges were induced in 11/12 cows between 15 and $79 \mathrm{~h}$ after implant insertion. There were no relationships amongst plasma oestradiol concentrations, LH pulse frequency, pretreatment FSH concentrations, timing of the LH surge or time to first rise in milk progesterone concentration. There was a negative correlation $(r=-0.58 ; P<0.05)$ between the stage post partum and the timing of the peak of the LH surge after implant insertion. Although the positive feedback mechanism was functional in most cows, the data may reflect a continuing recovery of the responsiveness of the hypothalamo-pituitary axis to the positive feedback effects of oestradiol-17 $\beta$ between Days 10 and 17 post partum.
\end{abstract}

\section{Introduction}

A number of components of the hypothalamo-pituitary-ovarian axis could potentially limit the onset of ovulation in the post-partum cow. These include tonic FSH (Dobson, 1978), LH (Lamming, Peters, Riley \& Fisher, 1982; Schallenberger, Oerterer \& Hutterer, 1982) and oestradiol-17 $\beta$ secretion (Lishman, Allison, Fogwell, Butcher \& Inskeep, 1979). Furthermore the hypothalamo-pituitary axis must be able to respond to high concentrations of oestradiol in blood in order to release the preovulatory gonadotrophin surges (Pope, 1982).

Several authors have suggested that FSH secretion is unlikely to be a limiting factor in the onset of ovarian activity post partum (Carruthers, Convey, Kesner, Hafs \& Cheng, 1980; Lamming et al., 1982; Schallenberger et al., 1982). The development of a pulsatile pattern of LH secretion is perhaps the most distinct endocrine event preceding the first ovulation (Carruthers \& Hafs, 1980; Peters, Lamming \& Fisher, 1981). Furthermore the induction of pulsatile LH release by repeated injections of 0.5 to $5.0 \mu \mathrm{g} \mathrm{GnRH}$ has resulted in ovulation in some acyclic cows (Riley, Peters \& Lamming, 1981; Walters et al., 1982), although this has not been consistently successful (Edwards, Roche \& Niswender, 1983).

Peripheral levels of oestradiol-17 $\beta$ fall after parturition and then fluctuate considerably before the first preovulatory peak of oestradiol-17 3 (Pope, 1982). During the oestrous cycle, increasing concentrations of oestradiol induce the preovulatory gonadotrophin surges possibly by effects both on the hypothalamus and pituitary gland (Kesner, Convey \& Anderson, 1981). The ability of physiological concentrations of oestradiol-17 7 to elicit this positive feedback response in the postpartum cow has received little attention. Therefore the present study was carried out to study the effect of exogenous oestradiol-17 $\beta$ on LH and FSH secretion in the post-partum period.

* Present address: Meat and Livestock Commission, Queensway House, Bletchley, Milton Keynes MK2 2EF, 


\section{Materials and Methods}

Twelve Hereford $\times$ Friesian cows calving between May and October and each suckling a single calf were used, starting between Days 10 and 17 post partum. The cows received one $(N=6)$ or two $(N=6)$ silicone rubber implants each containing $45 \mathrm{mg}$ oestradiol-17 $\beta$ (Compudose: Elanco Products Ltd, Basingstoke, U.K.) and designed to release $65 \mu \mathrm{g}$ steroid per day. Implants were washed in 50\% ethanol :50\% water and placed subcutaneously behind an ear ipsilateral to an indwelling jugular venous catheter and left in situ for 5 days.

Milk samples were taken for progesterone assay from all cows, three times weekly from calving until at least Day 50 post partum or until normal ovarian cycles were re-established. Blood samples $(5 \mathrm{ml})$ were taken via the indwelling jugular venous catheters at 15 -min intervals for $8 \mathrm{~h}$ before implant insertion. Additional single $25-\mathrm{ml}$ blood samples were taken on each day of the experiment to allow assay of oestradiol-17 $\beta$.

Milk progesterone assays were carried out as described by Bulman \& Lamming (1978). The sensitivity, intra-assay and inter-assay coefficients of variation (CV) were $0.4 \mathrm{ng} / \mathrm{ml}, 9.1$ and $11.0 \%$ respectively. Plasma LH and FSH concentrations were assayed by the method of Webb, Lamming, Haynes, Hafs \& Manns (1977) and Webb, Lamming, Haynes \& Foxcroft (1980) respectively. The sensitivity, intra-assay and inter-assay CVs for the LH and FSH assays were $0.30 \mathrm{ng} / \mathrm{ml}, 9.4$ and $11.0 \%$; and $11.5 \mathrm{ng} / \mathrm{ml}, 11 \cdot 0$ and $16 \cdot 1 \%$ respectively.

Plasma oestradiol- $17 \beta$ concentrations were assayed by the method of Glencross \& Pope (1981) with the modified extraction procedure of Glencross, Abeywardene, Corney \& Morris (1981). Oestradiol- $17 \beta$ was extracted from 5-ml plasma duplicates by a specific antibody bound to sepharose gel in glass columns and subsequently eluted with $95 \%$ acetone $: 5 \%$ water. The procedures and reagents were identical to those used in the above published reports. The mean recovery percentage for oestradiol- $17 \beta$ in unknown plasma samples was $52.5 \pm 1.6 \%$ (s.e.m.). Water blanks extracted and assayed in an identical manner to plasma samples consistently gave values $>95 \%$ of total binding. The sensitivity, intra-assay and inter-assay CVs were $8.0 \mathrm{pg} /$ tube $(1.6 \mathrm{pg} / \mathrm{ml}), 17.9$ and $22.8 \%$ respectively. Plasma $\mathrm{LH}$ pulses were defined as described previously (Riley et al., 1981) and results were analysed using Student's $t$ test and linear regression analysis. Mean data are expressed \pm s.e.m.

\section{Results}

Mean plasma oestradiol-17 $\beta$ concentrations before implant insertion were $4.25 \pm 0.51 \mathrm{pg} / \mathrm{ml}$. During the 5 days that implants were in place oestradiol concentrations increased to $16.57 \pm 3.66$ $\mathrm{pg} / \mathrm{ml}$ and $37 \cdot 10 \pm 9.1 \mathrm{pg} / \mathrm{ml}$ in the cows receiving one and two implants respectively. Before implantation mean plasma LH concentration was $2.02 \pm 0.12 \mathrm{ng} / \mathrm{ml}$, there were $4.2 \pm 0.30 \mathrm{LH}$ pulses per $8 \mathrm{~h}, \mathrm{LH}$ pulse amplitude was $2 \cdot 32 \pm 0.21 \mathrm{ng} / \mathrm{ml}$, and mean FSH concentration was 65.7 $\pm 8.4 \mathrm{ng} / \mathrm{ml}$. Typical LH and FSH profiles before implant insertion are shown in Text-fig. 1. FSH patterns were dissimilar from those of $\mathrm{LH}$ in that a discrete pulsatile pattern was not obvious. Frequent oscillations in plasma FSH concentrations occurred but these did not always conform to the definition of a 'pulse' as previously used (Riley et al., 1981). The peaks of the majority of LH pulses coincided with or occurred within 15 min of an FSH peak, although additional FSH peaks also occurred (see Text-fig. 1). There was a significant correlation between mean LH and FSH concentrations in the 12 cows during the pretreatment period $(r=0.554 ; P<0.05)$.

Preovulatory-type gonadotrophin surges occurred in all cows except Cow 5, between 15 and $79 \mathrm{~h}$ after implant insertion (see Table 1). Cow 5 had the lowest mean plasma LH and FSH concentrations during the pretreatment period $(1.32 \pm 0.08$ and $33.0 \pm 5.8 \mathrm{ng} / \mathrm{ml}$, respectively) and the lowest mean oestradiol- $17 \beta$ concentration after implant insertion $(8.60 \pm 0.98 \mathrm{pg} / \mathrm{ml})$.

Mean plasma $\mathrm{LH}$ concentrations at the peak of the preovulatory-type surge were $17 \cdot 22 \pm 2 \cdot 27$ 


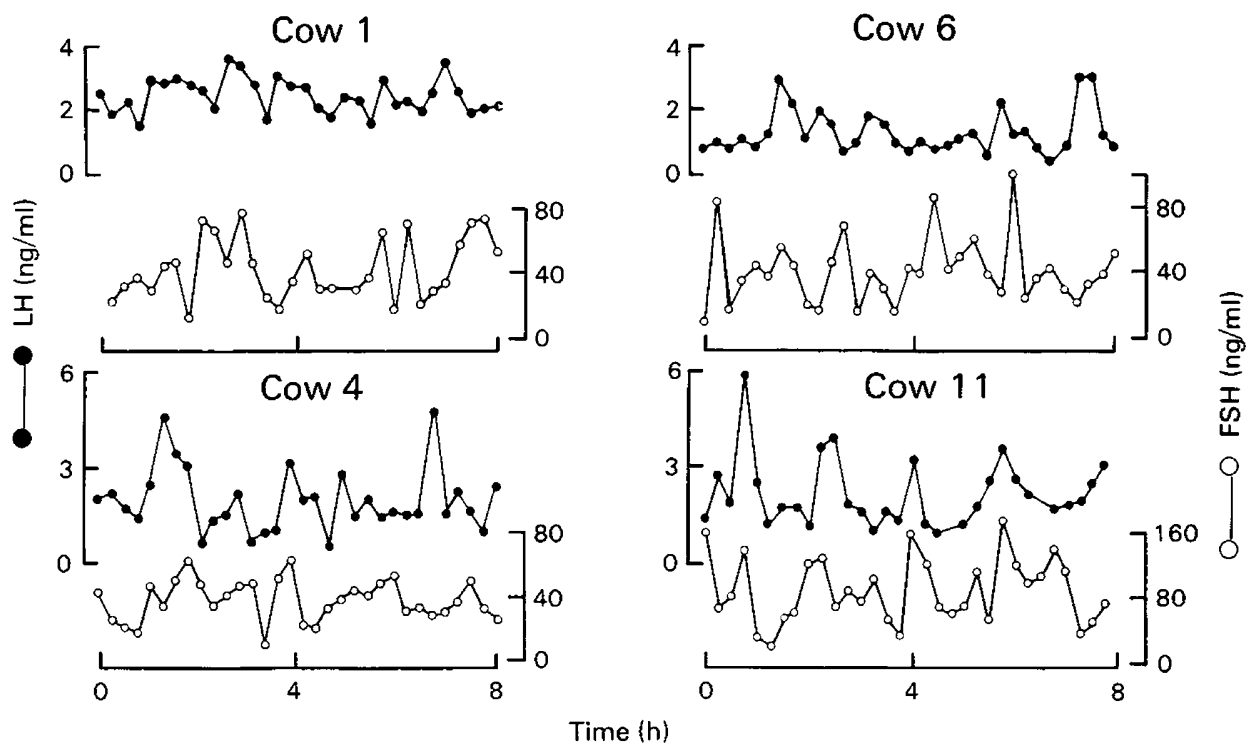

Text-fig. 1. Plasma LH and FSH concentrations $(\mathrm{ng} / \mathrm{ml})$ in 4 cows during the 8 -h pretreatment sampling period. Note the pulsatile pattern in the LH profiles but the less distinct patterns in the FSH profiles.

Table 1. The relationship between time post partum, time to the LH peak and the onset of ovarian activity in cows treated with one or two implants containing oestradiol-17ß

\begin{tabular}{ccccc}
\hline No. of implants & Cow no. & $\begin{array}{c}\text { Time } \\
\text { post partum } \\
\text { (days) }\end{array}$ & $\begin{array}{c}\text { Time to LH } \\
\text { peak (h) }\end{array}$ & $\begin{array}{c}\text { Time to first rise } \\
\text { in milk progesterone } \\
\text { concentration (days) }\end{array}$ \\
\hline 1 & 1 & 13 & 18 & 38 \\
& 2 & 13 & 32 & 23 \\
& 3 & 14 & 15 & 19 \\
& 4 & 10 & 79 & 33 \\
2 & 5 & 13 & - & $>50$ \\
& 6 & 14 & 33 & $>50$ \\
& 7 & 14 & 25 & 24 \\
& 8 & 14 & 31 & 34 \\
9 & 10 & 37 & 42 \\
& 10 & 17 & 22 & 35 \\
& 11 & 16 & 22 & $>50$ \\
\hline
\end{tabular}

and $32.60 \pm 3.20 \mathrm{ng} / \mathrm{ml}$ for cows receiving one and two implants respectively $(P<0.01)$. Mean peak FSH concentrations were $165.30 \pm 42.60$ and $294.20 \pm 39.50 \mathrm{ng} / \mathrm{ml}$ respectively for the same two groups $(P<0.05)$. There were significant correlations between mean oestradiol-17 $\beta$ concentrations after implant insertion and the peak values of $\mathrm{LH}(r=0.844 ; P<0.01)$ and FSH $(r=0.812 ; P<0.01)$. The mean LH and FSH surge responses of the 11 cows are shown in Text-fig. 2.

Overall there was a significant negative correlation between the day post partum on which cows were given implants and the time at which the peak of the LH surge occurred (mean $31.09 \pm$ $5.20 \mathrm{~h})$ after implant insertion $(r=-0.58 ; P<0.05)$. This relationship also existed in the group 


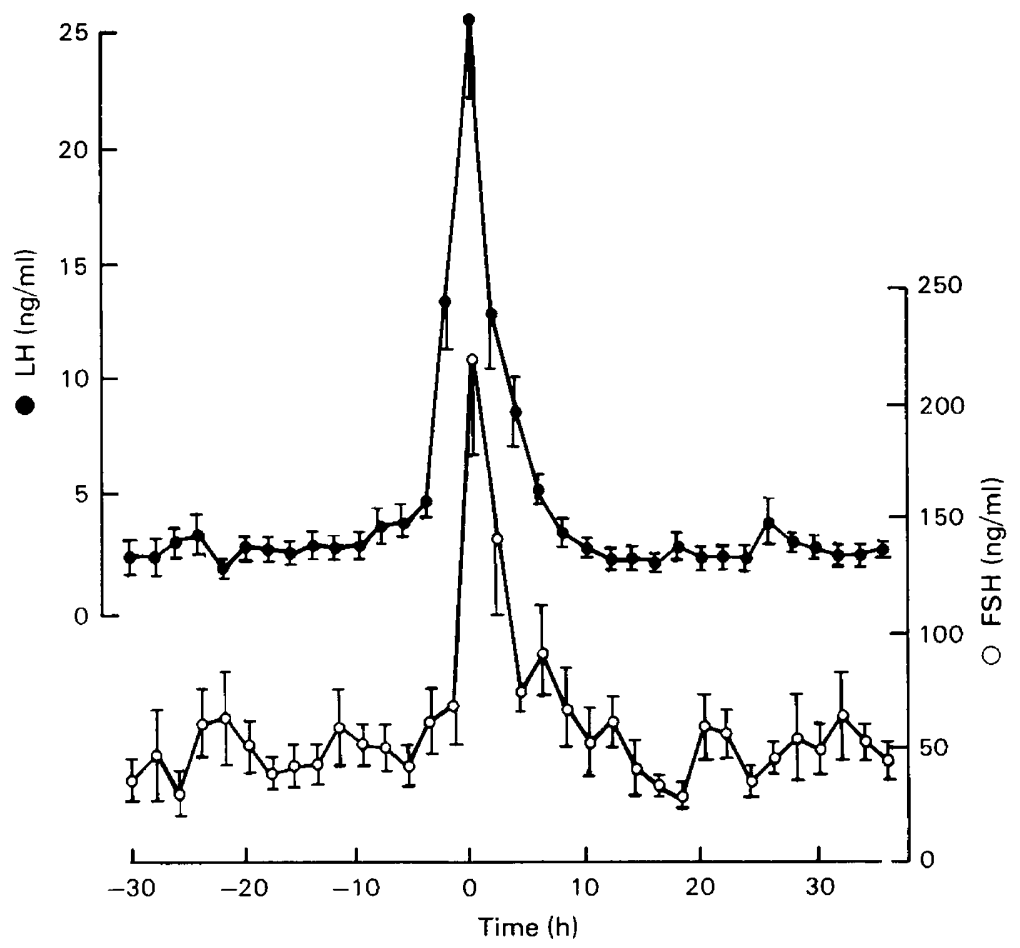

Text-fig. 2. Mean \pm s.e.m. plasma LH and FSH concentrations $(\mathrm{ng} / \mathrm{ml})$ in 11 cows which exhibited preovulatory-type gonadotrophin surges. Data are standardized to the peak of the LH surge.

receiving one implant $(r=-0.91 ; P<0.05)$ but just failed to reach significance in the group receiving two implants $(P=0.06)$. There was no correlation between oestradiol concentrations after implant insertion and timing of the gonadotrophin surges.

Apart from the correlations described above, there were no significant correlations between oestradiol-17 $\beta$ concentrations during the periods before or after implant insertion, LH concentrations, LH pulse frequency, FSH concentrations, stage post partum at treatment or the timing of the first rise in milk progesterone concentrations.

\section{Discussion}

Exogenous oestradiol-17 $\beta$ induced preovulatory-type gonadotrophin surges in $11 / 12$ cows. Whilst post-treatment concentrations of oestradiol-17 $\beta$ in cows receiving two implants were supraphysiological, those in cows receiving one implant were similar to those observed in cows at oestrus (Glencross \& Pope, 1981). No untreated control group of cows was included in the present study. However, the average time to the first significant rise in milk progesterone concentrations in similar cows calving at the same time of year was 35.9 days (Peters \& Riley, 1982; see Table 1). Progesterone concentrations usually begin to rise about 5 days after the LH surge (Schams, Schallenberger, Hoffmann \& Karg, 1977). It is therefore most improbable that a significant proportion of the gonadotrophin surges occurred spontaneously in the present experiment, since progesterone concentrations did not rise generally until much later (see Table 1). Additionally, in only two cows (Nos 4 and 9) was the plasma oestradiol-17 $\beta$ concentration $>5 \mathrm{pg} / \mathrm{ml}$ during the 
pretreatment period (7.00 and $6.50 \mathrm{pg} / \mathrm{ml}$ respectively), yet the gonadotrophin surges occurred relatively late in these two cows (Table 1).

The occurrence of gonadotrophin surges appeared to be unrelated to $\mathrm{LH}$ and FSH secretion before treatment since there were no correlations between surge timing and the initial concentrations of these hormones. Therefore, the responsiveness of the hypothalamo-pituitary axis to positive feedback may be independent of the rate of tonic gonadotrophin secretion. Conversely, the cow which failed to exhibit a preovulatory-type gonadotrophin surge had the lowest initial LH and FSH concentrations. This was further confounded by the fact that exogenous oestradiol-17 $\beta$ concentrations were also lowest in this cow and these may not have reached the threshold required to induce the preovulatory surge. Alternatively, a preovulatory-type surge may have occurred after the end of the blood-sampling period.

Discrete pulses of FSH analogous to those of LH were not observed, in accordance with our previous findings (Riley et al., 1981; McLeod, Haresign, Peters \& Lamming, 1984). However, oscillations in FSH concentrations occurred frequently but most did not fulfil our previous definition of a 'pulse' (Riley et al., 1981), in that there was often only a single elevated point between adjacent troughs. Most peaks of LH coincided with or occurred within $15 \mathrm{~min}$ of FSH peaks. Additional peaks in the FSH profiles were also observed, concurring with data obtained in another laboratory from cows during normal ovarian cycles (E. Schallenberger, personal communication).

The higher dose of oestradiol-17\% (two implants) resulted in significantly higher LH surges than in the cows receiving one implant. A positive dose-response relationship between exogenous oestradiol-17 $\beta$ and peak LH concentrations has been reported previously (Short, Randel, Staigmiller \& Bellows, 1979).

In the natural post-partum period oestradiol concentrations fluctuate considerably and may even reach preovulatory-type levels, although ovulation does not necessarily occur following these peaks (Pope, 1982). This suggests the possibility of a failure of the positive feedback mechanism during the early post-partum period. In the present study, there was a negative relationship between the stage post partum at implant insertion and the timing of the preovulatory-type gonadotrophin surges after implant insertion. One possible interpretation of this finding is that although the positive feedback mechanism was functional, recovery of maximal activity may have been continuing over the period studied. There appear to be no published reports describing in detail the time relationship between changing plasma oestradiol-17 $\beta$ and gonadotrophin concentrations at natural oestrus in the cow. When exogenous oestradiol-17 $\beta$ has been administered to ovariectomized cows, maximum LH concentrations were achieved between 12 and $23 \mathrm{~h}$ after injection (Forrest, Kaltenbach \& Dunn, 1981; Kesner et al., 1981). Schallenberger et al. (1982) injected dairy cows with $1 \mathrm{mg}$ oestradiol benzoate at various stages post partum and although no peak occurred at Day 5 there was a response at Day 15. Furthermore Short et al. (1979) reported that suckling inhibited the LH response to exogenous oestradiol relative to that in non-suckling cows during the post-partum period.

In the present study oestradiol treatment induced preovulatory-type gonadotrophin surges possibly by an increase in the rate or amplitude of GnRH secretion or an increase in pituitary sensitivity to GnRH stimulation. The results of Kesner et al. (1981) for ovariectomized cows indicate that a combination of these effects may occur. I conclude that the recovery of responsiveness of the hypothalamo-pituitary axis to the positive feedback effects of high plasma concentrations of oestradiol-17 $\beta$ is necessary before the first ovulation can occur in post-partum cows. In the present study the timing of the oestradiol-induced gonadotrophin surges between Days 10 and 17 were inversely related to the stage post partum.

I thank Mr and Mrs R. Temple, and Mr A. Dingle for technical help; the Meat and Livestock Commission and the Agricultural and Food Research Council for financial support; Elanco Products Ltd for the implants; and NIH (Bethesda) and Dr L. E. Reichert for the bovine LH and FSH. 


\section{References}

Bulman, D.C. \& Lamming, G.E. (1978) Milk progesterone levels in relation to conception, repeat breeding and factors influencing acyclicity in dairy cows. $J$. Reprod. Fert. 54, 447-458.

Carruthers, T.D. \& Hafs, J.D. (1980) Suckling and fourtimes daily milking: influence on ovulation, estrus and serum luteinizing hormone, glucocorticoids and prolactin in postpartum Holsteins. J. Anim. Sci. 50, 919-925.

Carruthers, T.D., Convey, E.M., Kesner, J.S., Hafs, H.D. \& Cheng, K.W. (1980) The hypothalamo-pituitary gonadotrophic axis of suckled and nonsuckled dairy cows postpartum. J. Anim. Sci. 51, 949-957.

Dobson, H. (1978) Radioimmunoassay of FSH in the plasma of post-partum dairy cows. J. Reprod. Fert. 52, 45-49.

Edwards, S., Roche, J.F. \& Niswender, G.D. (1983) Response of suckling beef cows to multiple, low-dose injections of Gn-RH with or without progesterone pretreatment. J. Reprod. Fert. 69, 65-72.

Forrest, D.W., Kaltenbach, C.C. \& Dunn, T.G. (1981) Estriol- and estradiol-17 $\beta$-induced luteinizing hormone release in ovariectomized cows and ewes. $J$. Anim. Sci. 52, 1106-1113.

Glencross, R.G. \& Pope, G.S. (1981) Concentrations of oestradiol-17 $\beta$ and progesterone in the plasma of dairy heifers before and after cloprostenol-induced and natural luteolysis and during early pregnancy. Anim. Reprod. Sci. 4, 95-106.

Glencross, R.G., Abeywardene, S.A., Corney, S.J. \& Morris, H.S. (1981) The use of oestradiol-17ß antiserum covalently coupled to sepharose to extract oestradiol-17 $\beta$ from biological fluids. J. Chromatogr. biomed. Applic. 223, 193-197.

Kesner, J.S., Convey, E.M. \& Anderson, C.R. (1981) Evidence that estradiol induces the preovulatory LH surge in cattle by increasing pituitary sensitivity to LHRH and then increasing LHRH release. Endocrinology 108, 1386-1391.

Lamming, G.E., Peters, A.R., Riley, G.M. \& Fisher, M.W. (1982) Endocrine regulation of post-partum function. In Factors Influencing Fertility in the Post Partum Cow, pp. 148-172. Eds H. Karg \& E. Schallenberger. Martinus Nijhoff, The Hague.

Lishman, A.W., Allison, S.M.J., Fogwell, R.L., Butcher, R.L. \& Inskeep, E.K. (1979) Follicular development and function of induced corpora lutea in underfed postpartum anestrous beef cows. J. Anim. Sci. 48, $867-875$.
McLeod, B.J., Haresign, W., Peters, A.R. \& Lamming, G.E. (1984) Plasma LH and FSH concentrations in prepubertal beef heifers before and in response to repeated injections of low doses of Gn-RH. J. Reprod. Fert. 70, 137-144.

Peters, A.R. \& Riley, G.M. (1982) Milk progesterone profiles and factors affecting post partum ovarian activity in beef cows. Anim. Prod. 34, 145-153.

Peters, A.R., Lamming, G.E. \& Fisher, M.W. (1981) A comparison of plasma LH concentrations in milked and suckling post-partum cows. J. Reprod. Fert. 62, $567-573$.

Pope, G.S. (1982) Oestrogens and progesterone in plasma and milk of post-partum dairy cattle. In Factors Influencing Fertility in the Post Partum Cow, pp. 248276. Eds H. Karg \& E. Schallenberger. Martinus Nijhoff, The Hague.

Riley, G.M., Peters, A.R. \& Lamming, G.E. (1981) Induction of pulsatile $\mathrm{LH}$ release, FSH release and ovulation in post-partum beef cows by repeated small doses of Gn-RH. J. Reprod. Fert. 63, 559-565.

Schallenberger, E., Oerterer, U. \& Hutterer, G. (1982) Neuroendocrine regulation of post-partum function. In Factors Influencing Fertility in the Post-Partum Cow, pp. 123-147. Eds H. Karg \& E. Schallenberger. Martinus Nijhoff, The Hague.

Schams, D., Schallenberger, E., Hoffmann, B. \& Karg, H. (1977) The oestrous cycle of the cow: hormonal parameters and time relationships concerning oestrus, ovulation, and electrical resistance of the vaginal mucus. Acta endocr., Copenh. 86, 180-192.

Short, R.E., Randel, R.D., Staigmiller, R.B. \& Bellows, R.A. (1979) Factors affecting estrogen-induced LH release in the cow. Biol. Reprod. 21, 683-689.

Walters, D.L., Short, R.E., Convey, E.M., Staigmiller, R.B., Dunn, T.G. \& Kaltenbach, C.C. (1982) Pituitary and ovarian function in post-partum beef cows. III. Induction of estrus, ovulation and luteal function with intermittent small-dose injections of GnRH. Biol. Reprod. 26, 655-662.

Webb, R., Lamming, G.E., Haynes, N.B., Hafs, H.D. \& Manns, J.G. (1977) Response of cyclic and postpartum suckled cows to injections of synthetic LHRH. J. Reprod. Fert. 50, 203-210.

Webb, R., Lamming, G.E., Haynes, N.B. \& Foxcroft, G.R. (1980) Plasma progesterone and gonadotrophin concentrations and ovarian activity in post-partum dairy cows. J. Reprod. Fert. 59, 133-143. 